\title{
XVI. Description of a new thrashing machine
}

\section{Richard Tawney Esq.}

To cite this article: Richard Tawney Esq. (1812) XVI. Description of a new thrashing machine, Philosophical Magazine Series 1, 40:172, 81-83, DOI: 10.1080/14786441208638192

To link to this article: http://dx.doi.org/10.1080/14786441208638192

$$
\text { 曲 Published online: } 27 \text { Jul } 2009 .
$$

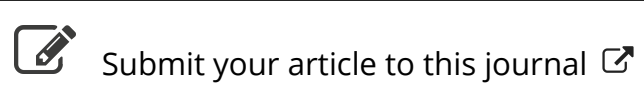

\footnotetext{
Џ Article views: 2
}

Q View related articles $\asymp$ 
XVI. Description of a new Thrashing Machine. By RichaRd TAWney, Esq.

\section{To Mr. Tilloch.}

SIR, $I_{r}$ having been long thought in this part of the kingdom a desideratum to unite in a thrashing machine with a small power the qualities of clean and good work; the following description, accompanied by a drawing of one which a short time since I had made for my own use, and which most effectually answers the purpose, will, perhaps, be not unworthy a place in the Philosophical Magazine.

I was induced to the attempt by observing that in every machine in this neighbourhood, both fixed and portable, a very large portion of the power was lost by friction, seldom less than half, and wished to try what could be effected by a machine constructed with a view to reduce the friction as much as possible.

The drawing presents an elevation and section of a machine to be worked by two men, with each a winch upon the axis of a wheel (which, as they could not be well shown in a geometrical view, are purposely omitted) turning by a small rope a pulley fixed upon the axis of the drum.

It will be seen that the wheel is hung upon friction rollers, and it was my intention to bave put rollers to the drum axis as well; but as these were found to enhance the price, and thereby defeat the general utility of the plan, the latter were omitted, and the friction kept down by making the brasses and axis as perfect and as small as they well could be with safety.

It should be mentioned that the drum, rollers, and plates, are upon the principle of the machines made by a Mr. Wilson, of Leicester, which for quantity and goodness of work are the best of a great number that I have seen. In these maclines, as will be observed in the section, the feed rollers are placed horizontally, and they are fed by laying the corn upon a board inclining to them from the top. One roiler is turned by a small strap from the drum axis; and as the two are made to touch by a thin well turned iron wheel or flanch at each end, the other roller is moved by friction.-Lest this should be thought strange in a machine purposely made to aroid friction, it must be remembered ihat, as the wheels are small, the points of contact are trifling, and that there are no other means of obtaining an equable motion so good.

Vol. 40. No. 172. August 1812. 
The axis of the second roller is hung at each end upon a pivot, so that when the feed is too great the roller will open, and be brought back again by a weight suspended at the end of a small lever.

The drum is made open, and the beaters fixed upon a ring at each end.

My machine is greatly improved by giving the drum (as well as the large wheel) a fly motion. The rings are mide thin and light of wood, and the beaters of bar iron. 'The more simples way perhaps would be to make the rings of cast iron, and throw the weight to the rim.

The leading feature of Mr. Wilson's machine is the situation of the parallel ribbed plates against which the corn is beaten or rubbed. Compared with other machines, they may be said to be divided: one part is fixed upon the levers which carry the feed rollers, the distance of which is regulated by a screw through the top of the frame; - the other is fixed in the frame which carries the iron grating, and with that the distance is regulated by a screw at each còmer.

It will be seen that the straw after passing the first p'ate may take a different.direction before it enters upon the second plate and grating, and to this circumstance I think is to be attributed the machine's superior work. By placing the feed rollers so far from the ribbed plate, and beaters, the straw is not at all hroken, but will admit of being tied up in boltings, as well as if thrashed by the flail.

The great wheel of this machine is six feet six inches diameter-to avoid resistance from the air, it is but two inches in thickness, and the spokes are made elliptical. To give it a fy motion, fitty-six pounds of cast iron are added to the ends of the spokes, as described in the elevation. This weight is sufficient to lead the men on, so that the difficulty is not to keep them up to a certain number of revolutions per minute, but to dissuade them from doing too much.

The pulley hitherto worked upon the drum has been either one-eighth or one-tenth the diameter of the wheel; and as in working the former is lighter, I find the velocity of the hand increased in proportion. The minimum velocity of the hand is forty revolutions per minute, and this carries the drum through a greater space than that of any ordinary machine of two or four borse power.

The winches at first were made to describe a circle of thirty-six, but were subsequently shortened to one of thirty inches diameter. 
The rope is of the best tarred kind one inch and a half in circumference, and spliced together.

The carriages of the wheel are each fixed to the frame by two screw pins, and the variation of the rope is remedied by slackening of the nuts.

What this machine will thrash when corn yields well, I am not prepared to say.

It has been tried with the worst of every sort of grain, and thrashed it perfectly clean.

With the labour of two men, and that about the same as when using the flail, it thrashed of the last season from thirty to thirty-six bushels (eight and half gailon measure) of wheat per day, which will warrant an expectation of considerably more in a good yielding year.

In the late wet spring I found it exceedingly useful to employ my men on those days when nothing out of doors could be done; and althrugh with a winch it may be not quite applicable to the case of every large farmer, still I am persuaded a considerable part of the farming interest will find it of real advantage as an auxiliary, if not a principal machine, and to the sinall nccupier I can recommend it as the most effective hand machine yet in use.

$$
\begin{gathered}
\text { I ain, sir, } \\
\text { Your most obedient servant, } \\
\text { Dunchurch Lodge, May 2, } 1812 . \quad \text { Richard Tawney. }
\end{gathered}
$$

XVII. An Account of some Experiments on the Comlinations of different Metals and Chlorine, \&6c. By JoH DAvx, Es $q$. Communcated ly Sir Humphry Davy, Knt. LL.D. Ser. R.S.

[Continued from p. 12,]

\section{On ttre Combinations of Iron and Chlorine.}

As there are two oxides of iran, so there are also two distinct combinations of this metal and chlorine. One may be directly formed by the combustion of iron wire in chlorine gas; it is that volatile compound described by Sir Humphry Davy in his last Bakerian Lecture, which condenses after sublimation in the form of small brilliant iridescent plates. The other, I find, may be procured by heating to redness, in a glass tube $u$ ith a very small orifice, the residue which is obtained by evaporating to dryness the green muriat of iron; it is a fixed substance requiring a red heat for its fusion; it is of a grayish but variegated colour, 